\title{
A marriage of convenience or an amicable divorce: Metaphorical blends in the debates on Brexit
}

\author{
Sanja Berberovićn \& Mersina Mujagić ${ }^{2}$ \\ ${ }^{1}$ Faculty of Humanities and Social Sciences, University of Tuzla \\ 2 Pedagogical Faculty, University of Bihać
}

\begin{abstract}
The paper investigates the interaction of conceptual blending and conceptual metaphor in producing figurative creativity in discourse. The phenomenon of figurative creativity is defined by Kövecses (2005) as creativity arising through the cognitive mechanisms of metonymy, metaphor, and blending. Specifically, the paper examines the use of creative figurative language in the British public discourse on the topic on Brexit. The aim of this paper is to show that conventional metaphors can be creatively stretched through conceptual blending, producing instances of creative figurative language. Specifically, applying blending theory, we will analyse innovative conceptual blends, motivated by the conventional MARRIAGE/DIVORCE metaphor. In addition, the paper also examines the way in which creative figurative language produced in metaphorical blends provides discourse coherence at intertextual and intratextual levels.
\end{abstract}

Key words: blending theory; cognitive metaphor theory; metaphorical blends; figurative creativity; intertextual and intratextual coherence; the MARRIAGE/DIVORCE metaphor.

\section{Introduction}

Cognitive metaphor theory and conceptual integration theory, or blending theory, are cognitive linguistic theories that have acquired a prominent status within the cognitive linguistic framework over the course of the past several decades. Cognitive metaphor theory has been successfully used in the study of language for the past several decades, producing evidence that metaphor is a cognitive mechanism of the utmost importance in the human conceptualization of the world. Blending theory has been used to account for a wide range of phenomena of human thought and action, from counterfactuals to metaphors, proving blending to be present in the simplest kinds of 
human thinking. Although these two theories are often presented as conflicting theories, in many cognitive linguistic studies they have been regarded as complementary theories, which share some common features as basic cognitive operations and which can benefit from each other.

The present paper discusses the interaction of these two cognitive operations, that is, conceptual blending and conceptual metaphor, in producing creative figurative language or figurative creativity in discourse. The phenomenon of figurative creativity is defined by Kövecses (2005) as creativity arising through the cognitive mechanisms of metonymy, metaphor, and blending. Specifically, the paper examines the use of creative figurative language in the British public discourse in discussing the exit of the United Kingdom from the European Union. The aim of this paper is to show that conventional metaphors can be creatively stretched through conceptual blending, producing instances of creative figurative language. Specifically, applying blending theory, we will analyse innovative conceptual blends, motivated by the conventional MARRIAGE/DIVORCE metaphor. In addition, the paper also examines the way in which creative figurative language produced in metaphorical blends provides discourse coherence at the intertextual and intratextual levels.

\section{Blending theory and cognitive metaphor theory}

Cognitive metaphor theory (henceforth CMT) and conceptual integration theory, or blending theory (henceforth BT), are cognitive linguistic theories whose primary goal is to uncover the meaning construction and thus account for the complexities of the human mind. CMT, first discussed at length in Lakoff and Johnson's (1980) Metaphors We Live By, and subsequently further developed in Lakoff $(1987,1993)$, Lakoff and Turner (1989), Lakoff and Johnson (1999), Kövecses (2002, 2005, 2010a, 2015), has been successfully used in the study of language showing that metaphor is a cognitive mechanism of the utmost importance in the human conceptualization of the world. In 1993, Fauconnier and Turner built BT on the foundations of Fauconnier's (1985) mental space theory. The basic ideas behind blending theory have since been elaborated in the works of Fauconnier and Turner ([1998] 2006, 2000, 2002, Turner and Fauconnier (1995, 1999, 2003), Turner (2007), Coulson and Oakley (2000), Grady et al. (1999). This theory has been successfully used to account for a wide range of phenomena of human thought and action, from counterfactuals to metaphors showing that blending is present in the simplest kinds of human thinking.

Although both CMT and BT have been criticized in numerous linguistic studies written within different theoretical frameworks, as well as within the 
cognitive linguistic framework, proposing alternative approaches or simply pointing out the weaknesses of the theories, both theories have found their application in explaining the construction of meaning of a variety of phenomena. ${ }^{1}$ In addition, the proponents of BT and CMT have often directed criticism against each other, comparing and contrasting these two theories in search of the flaws or advantages of one of these theories. While the proponents of BT claim that CMT is not equipped with mechanisms to account for the integration processes arising in the blended space, proponents of CMT often emphasize that there is no need to use BT, which at times seems to be too powerful, instead of CMT because in the concrete cases that they discuss CMT is capable of elegantly explaining the construction of meaning.

Regardless of the criticism, these two theories are also often presented as complementary models in the cognitive linguistic literature, having complementary aims but dealing with different aspect of the same phenomenon. CMT has been focused on finding conventional patterns of metaphorical conceptualization, while BT has been dedicated to investigating novel examples. "While the metaphor theorist strives to capture generalizations across a broad range of metaphoric expressions, the blending theorist typically focuses on the particulars of individual examples" (Grady et al., 1999: 121). ${ }^{2}$ Furthermore, in his discussion of image schemas, domains, frames, and mental spaces as representing four different levels which form a schematic hierarchy, Kövecses (2017: 345) claims that BT operates on the level of mental spaces, while CMT operates on levels higher than mental spaces, that is, frames, domains, and image schemas. Kövecses (2017: 345) concludes that "blending relies heavily on frames and domains, and CMT is incomplete as a theory without taking into account what happens at the least schematic level of mental spaces".

\footnotetext{
${ }^{1}$ Such criticism is quite common in the cognitive linguistic literature. Some of the papers which offer criticism of BT are Gibbs (2000), Ruiz de Mendoza (1998), Ruiz de Mendoza and Peña Cervel (2002), Ruiz de Mendoza and Díez (2003), and Brandt and Brandt (2005). In addition, alternative approaches to BT are proposed by Brandt and Brandt (2005) and Ruiz de Mendoza and associates in a series of papers (Ruiz de Mendoza, 1998; Ruiz de Mendoza and Peña Cervel, 2002; Ruiz de Mendoza and Díez, 2003). As for CMT, an article by Kövecses (2008) summarizes issues which have been subject to criticism and provides arguments against the criticism. In addition, Kövecses (2011) also compares conceptual metaphor theory with alternative, modified, and refined approaches to metaphor.

2 Kövecses (2005: 259ff) presents convincing arguments that both theories are capable of dealing with, what he calls, figurative creativity, each contributing to this issue operating within its own scope. Furthermore, the studies dealing with metaphorical creativity in discourse Kövecses $(2005,2009 a, 2009 b, 2009 c, 2010 a, 2010 b, 2015)$, Semino (2002, 2008), Koller (2004a, 2004b) and Musolff $(2000 b, 2004 a, 2016)$ show that CMT does not only deal with conventional metaphorical expressions, but it can deal with creative expressions. In addition, Fauconnier (2009) shows that BT is not limited only to isolated innovative examples but it can point out generalizations as well. In addition, Coulson and Pagán Cánovas (2013) claim that since the publication of Grady at al.'s (1999) paper many studies have shown increasing convergence of the two theories.
} 
CMT and BT share some common features; both are basic cognitive operations, which are pervasive in human thought and action, involve mappings, and are governed by certain constraints. However, differences, which can be regarded as their defining properties, between the two theories exist.

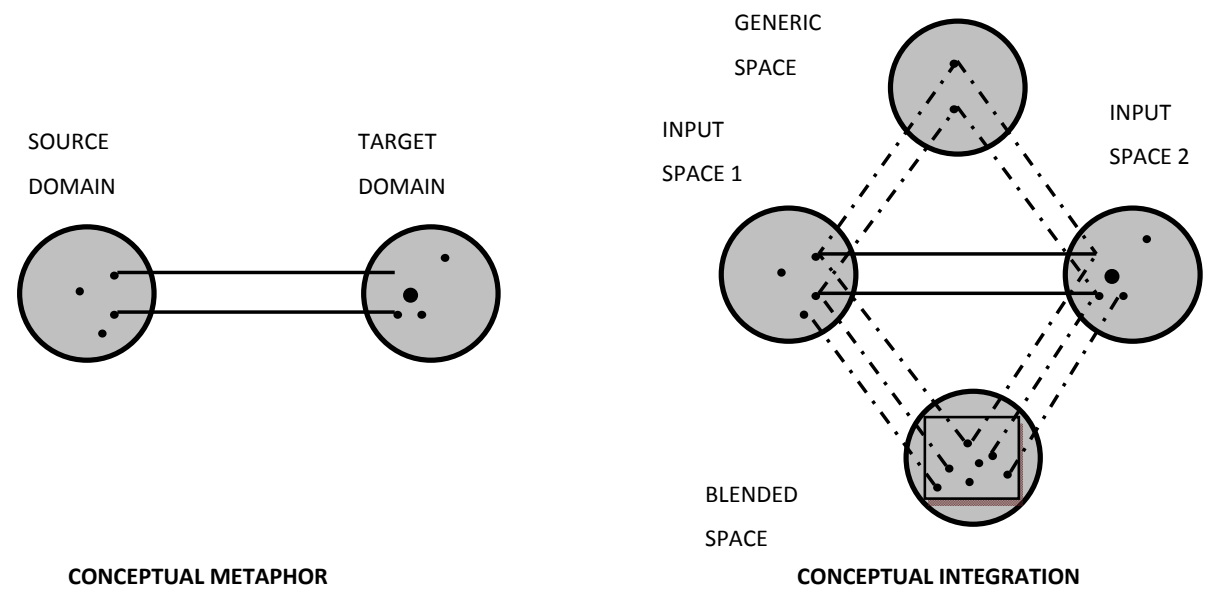

Figure 1. Comparison between conceptual metaphor and conceptual blending.

The basic and most obvious difference between CMT and BT is that the former operates over two conceptual domains, while the latter deals with four mental spaces.

Furthermore, compared to domains employed in CMT, defined as "any coherent organization of experience" (Kövecses 2002: 4), mental spaces are smaller conceptual packets, which are usually more specific and comprise knowledge from many different domains. Fauconnier and Turner (2002: 40) define mental spaces as "small conceptual packets constructed as we think and talk, for purposes of local understanding and action". Direction of mappings is another difference between these two theories. Mappings in CMT proceed from a concrete source domain onto an abstract target domain. In BT, mappings are established between mental spaces, generic space, and blended space. In metaphorical blends, conceptual material is projected from both input spaces into the blended space. In addition, the reconceptualization of the target input space by projections of inferences from the blended space is possible in BT.

The proponents of BT point out that the theory was designed to account for a wider range of phenomena of human thought and action than CMT, such as counterfactuals, analogy, concept combination, including metaphor and metonymy (Coulson and Oakley, 2000; Turner and Fauconnier, 2003). In 
numerous papers, the proponents of BT claim that, apart from metaphoric projections from source to target domains, complex integration processes construct blended spaces, which have often gone unnoticed in the twodomain model (cf. Fauconnier and Turner, 2008; Turner and Fauconnier, 1995, 2003; Coulson, 1996). “The many-space model explains a range of phenomena invisible or untreatable under the two-domain model and reveals previously unrecognized aspects of even the most familiar basic metaphors" (Turner and Fauconnier, 1995: 184). To support this claim, Turner and Fauconnier offer a wealth of examples of metaphorical blends in which inferences in the blended space cannot be explained by simple source to target mappings. Therefore, they propose BT as an alternative and comprehensive approach, which can account for the complex cognitive processes taking place in the construction of meaning, prompting cognitive linguists to "rethink metaphor", as the title of one of Fauconnier and Turner's (2008) papers states.

One such example is the metaphor My surgeon is a butcher, ${ }^{3}$ a statement about an incompetent surgeon, which is often discussed in the cognitive linguistic literature. Grady et al. (1999: 103ff) claim that the two-domain model cannot explain the main idea behind this statement, namely that the surgeon is incompetent. These claims are based on the consideration of basic mappings from the source domain onto the target domain. In the twodomain model, the butcher maps onto the surgeon; the cleaver maps onto the scalpel; the animal maps onto the human being; abattoir maps onto operating room; commodity maps onto the patient; cutting meat maps onto cutting flesh. However, Grady et al. conclude that these basic mappings cannot account for the meaning that the surgeon is incompetent because the concept of incompetence is not among the elements mapped from the source onto the target. Therefore, the application of blending theory provides a detailed explanation of how the inference that the surgeon is incompetent emerges.

\footnotetext{
${ }^{3}$ Kövecses (2011) uses this particular metaphorical sentence to compare the standard conceptual metaphor theory with different theories of metaphor (the categorization view of metaphor, blending theory, the combination of neural theory of metaphor and Lakoff and Johnson's conceptual metaphor theory, and conceptual metaphor theory as based on the idea of the main meaning focus.
} 


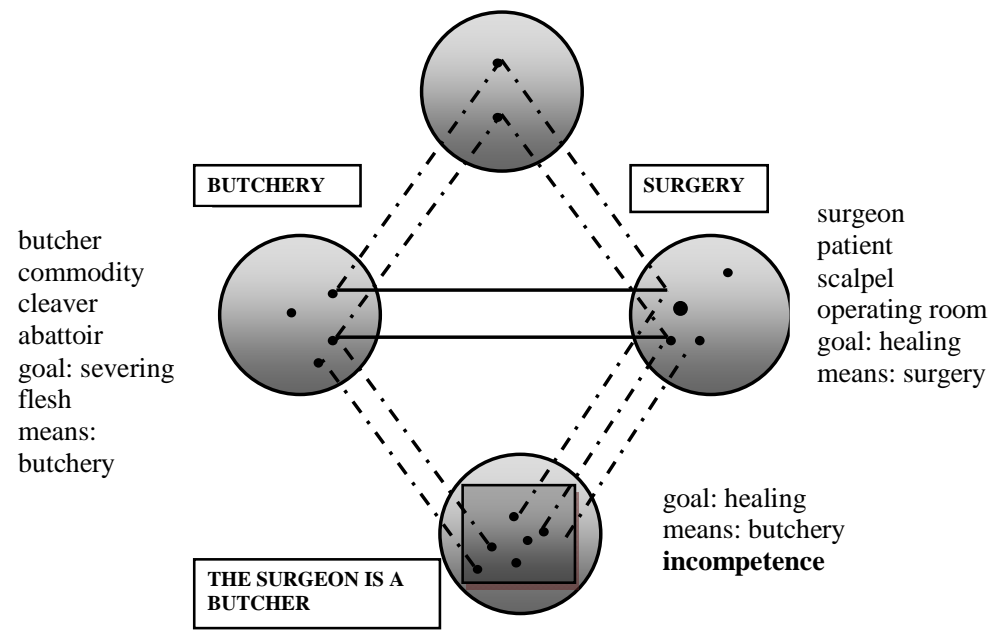

Figure 2. Conceptual integration network for surgeon is a butcher (adapted from Grady et al., 1999: 105)

In the four-space model, the blend inherits the structure of the input spaces, namely, from the domain of surgery it takes the identity of the person being operated, the identity of the person performing the surgery, and the setting of the operating room. From the domain of butchery, the blend inherits the role of butcher and the activities associated with that role. The generic space contains elements that are shared by both inputs, namely an individual uses a sharp instrument to perform an activity on another individual. Furthermore, the emergent content of the blend develops by combining elements from the inputs. The two inputs have incompatible means-end relationships, namely the goal of butchery is to kill the animal and cut its flesh, while the goal of surgery is to heal the patient. In the blended space, the means of butchery combine with the goal of surgery producing the inference that the surgeon is incompetent.

This example emphasises the reasons why the proponents of BT claim that this theory can explain the construction of meaning in metaphorical blends more accurately. However, metaphor does play an important role in conceptual blending. As pointed out, metaphor as a cognitive mechanism is presupposed in BT. As Grady et al. (1999: 111) argue, conventional metaphors serve as triggers for launching the blends by providing counterpart mappings between input spaces (cf. Grady et al., 1999; Turner and Fauconnier, 2003; Fauconnier and Turner, [1998] 2006, [1998] 2001).

If conceptual metaphor theory is primarily concerned with well-established metaphoric associations between concepts, and blending theory focuses on the ability to combine elements from familiar conceptualizations into new and meaningful 
ones, then conceptual metaphors are among the stable structures available for exploitation by the blending process. (Grady et al., 1999: 110)

From this view, "conventional metaphors feed the blending process by establishing links between elements in distinct domains and spaces" (Grady et al., 1999: 110). They further point out that metaphorical associations of this sort are part of human conceptual repertoires. BT can benefit from the findings of CMT, as counterpart mappings between concepts have been the focus of CMT investigations for a long time.

Similarly, Fauconnier and Turner ([1998] 2001) point out that blending is always available once a conventional metaphor is activated. Therefore, as previously mentioned, conventional metaphors are available for the elaboration in the blending process. However, it must be kept in mind that blending does not have to be based on metaphors, but it can involve other types of relations. Nevertheless, conventional metaphors do have a significant role in blending. As Fauconnier and Turner ([1998] 2006: 360) summarize it,

... a counterpart mapping is needed to launch on-line blending, and that counterpart structure is often supplied by activating a conventional metaphor, and the counterpart structure may have been created by the basic metaphor projection rather than merely picked out as a template for the projection.

In addition, this can lead to establishing conventional metaphors. As Fauconnier and Turner ([1998] 2001) claim, establishing conventional metaphorical mappings involves conceptual blending.

In cases where useful inferences or structure have been projected from the blend to the target so that the mapping from source to target becomes thoroughly conventional, and the blend is no longer a working space, it is possible to overlook both blend and generic space. (Fauconnier and Turner, [1998] 2001)

Considering the above-mentioned claims, CMT and BT are closely related and can interact with each other in various ways, which can be represented as in the diagram below. It can be assumed that conventional metaphors are products of novel blends, which have become conventionalized and entrenched during the course of time. In turn, conventional metaphors may become readily available sources for further elaboration in conceptual blending. It can be further assumed that such blends can potentially become entrenched and conventionalized conceptual metaphors, and that such processes could be repeated. 4

\footnotetext{
${ }^{4}$ A similar view on the interaction between metaphors and blends is presented by Matovac and Tanacković Faletar (2009).
} 


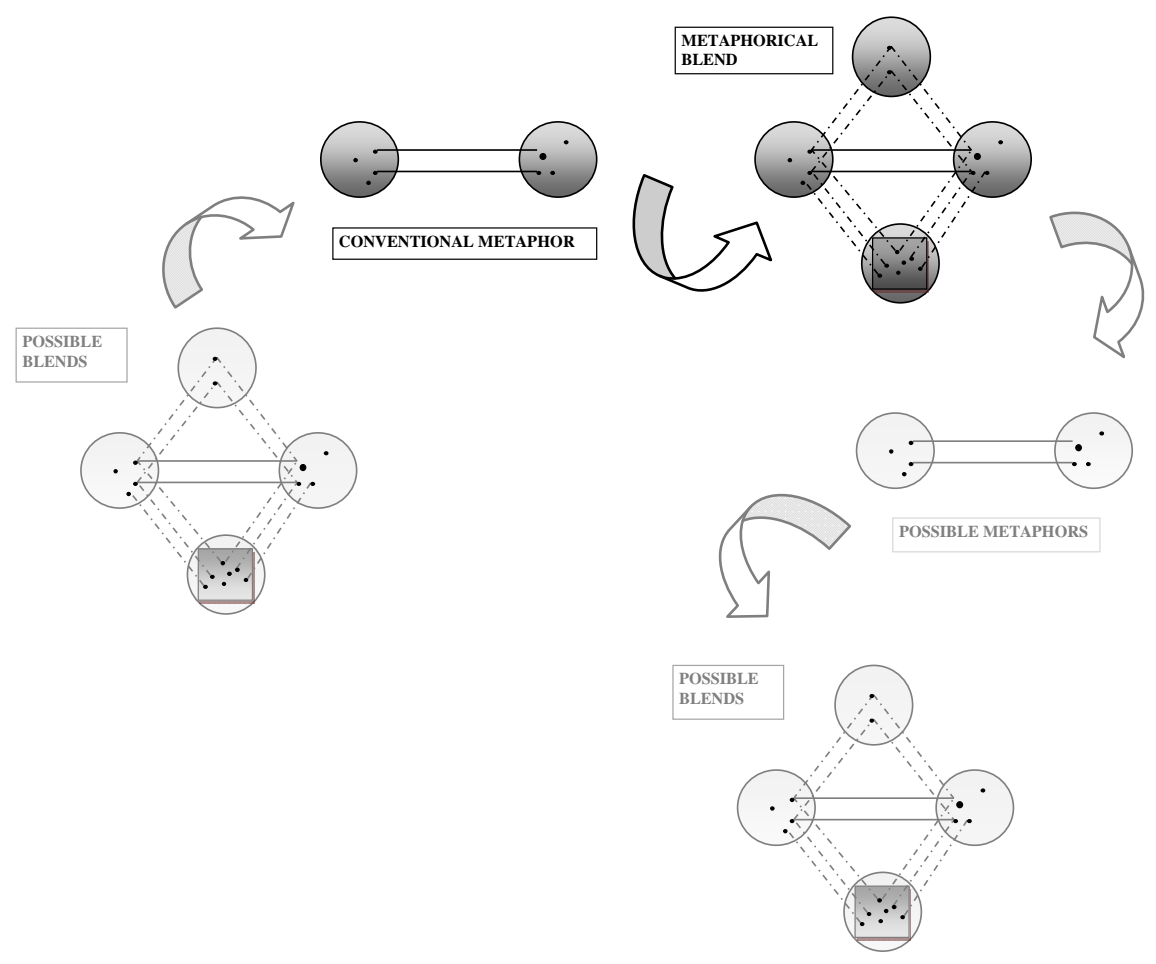

Figure 3. Cognitive processes involved in the production of figurative creativity.

\section{Brexit as a divorce}

Brexit is a lexical blend of the words 'British' or 'Britain' and 'exit' and has been extensively used to refer to the UK's withdrawal from the EU that started in 2016. Although the UK was part of the European Union from the very beginning, its relationship with the EU has been very tumultuous due to different reasons. In a referendum held in June 2016, the British people voted to leave the European Union. Thus, due to apparent differences in economic and political goals, lack of trust and sense of unity, the UK and the EU member states began a two-year-long process of administrative, political, and economic separation.

The amount of public interest and the importance of this issue have resulted in an open debate on Brexit in public discourse in the UK, which has been enriched by the use of figurative language, often very creative, that is, 
figurative creativity. The use of figurative language in the EU discourse has been extensively studied within the framework of cognitive linguistics, especially CMT (cf. Chaban et al., 2007; Đurović and Silaški, 2018; Musolff, 2000a, 2000b, 2001, 2004a, 2004b, 2006, 2009, 2010, 2016, 2017a; Petrica, 2011; Šarić, 2005; Werkmann and Buljan, 2013). Such studies deal with the use of metaphors in public discourse of different member and non-member EU countries, concentrating on different languages and comparing and contrasting national discourses of the EU members and the EU candidate countries. Some of these studies also show that the use of certain conceptual metaphors reveals cultural biases of the nation using these metaphors. Furthermore, the choice of metaphor in a national discourse can reveal attitudes towards Europe.

In addition, these studies also reveal that different conceptual metaphors are used for the conceptualization of various aspects of the European Union and the relationships among the member states. ${ }^{5}$ Musolff (2004a), for example, finds that some of the common metaphors for the conceptualization of the EU in the public discourse in the UK and Germany include, THE EU IS A BUILDING, THE EU IS A FAMILY/ LOVE RELATIONSHIP, THE EU IS A (HUMAN) BODY, THE EU IS MOVING ALONG A PATH. Particularly prominent among conceptual metaphors used in the EU discourse is the FAMILY metaphor, ${ }^{6}$ used for the conceptualization of the unity of the EU, as well as the complicated relationships between the member states, and their relationship with the EU institutions (cf. Đurović and Silaški, 2018; Musolff, 2001, 2004a, 2009, 2016). Therefore, it is not surprising that Brexit, which is a metaphor itself, ${ }^{7}$ has been

${ }^{5}$ The most comprehensive study of metaphor in public discourse of the EU is provided by Musolff (2004a). His corpus study, containing data from the UK and Germany, provides insights into different attitudes towards the European Union of these two countries. It must be noted that Musolff (2000a, 2000b, 2001, 2004b, 2006, 2009, 2010, 2016, 2017a, 2017b) deals with metaphor in the EU discourse in a series of papers published before the publication of the above-mentioned book, and he continues his research in the studies published recently.

${ }^{6}$ The importance of the FAMILY metaphor in politics is discussed by Lakoff (1996). Lakoff claims that the liberal and conservative politics in America are guided by two opposing conceptualizations of the nation as a family, the nutrient parent model and the strict father model, in which the government is the father and citizens are the children. In his corpus study of the EU discourse, Musolff (2016: 31-33) finds that there are three metaphorical scenarios representing different aspect of the relationships between the EU and its member states. These are PARENTCHILD relationship (members are represented as marriage partners or children), MARRIED LIFE (hierarchical relationship with the Franco-German couple or the EU Commission dominating the rest) and MARRIAGE problems (asymmetric marriage relationship between the EU and the $\mathrm{UK})$.

${ }^{7}$ In Lakoff's opinion (2016), "the metaphor of entering and leaving the EU is based on a universal metaphor that states are locations in space: you can enter a state, be deep in some state, and come out that state". He draws an analogy with a café and explains:

"If you enter a café and then leave the café, you will be in the same location as before you entered. But that need not be true of states of being. But that was the metaphor used with Brexit; 
conceptualized as a divorce between the UK and the EU, ending a fourdecade-long political, economic, and administrative marriage between them. In that sense, Musolff (2017a: 4) finds that, in his preliminary analysis of a fairly large number of the UK press articles discussing Brexit, the most common and prominent source concepts used in the conceptualization of Brexit, among others (war, journey, natural disaster, gamble and body/heart), include divorce.

Considering the prominence the MARRIAGE/DIVORCE metaphor has had in the debate on Brexit, our analysis focuses on this metaphor used in the British public discourse in the pre and post Brexit period. In the British public discourse, Brexit metaphorically means that Britain is ready to file for divorce, pay divorce settlement, negotiate divorce, and as the UK readies divorce papers from the EU, it will conduct divorce talks, divorce negotiations, all in the hope for a civilised divorce because the relationship with the EU has always been a troubled marriage, never a tight love affair. Similarly, the examples in (1) all contain the conventional metaphoric linguistic expressions of the MARRIAGE/DIVORCE metaphor used in relation to Brexit.

(1) a. The two-year countdown to Brexit has begun badly. That's to be expected in a breakup after four decades of marriage. (The Guardian, The Guardian view on Brexit divorce: full of needless but expected provocations, March 31, 2017)

b. "It's been a long marriage between members of the European Union. It's my personal hope that it doesn't break. And like all marriages, good talks can actually help," she said at the IMF and World Bank's spring meetings in Washington. (The Guardian, IMF chief issues impassioned plea for Britain to stay in EU, April 14, 2016)

c. As is often the way, the nine intervening months have seen a lot of posturing. Britain has threatened to walk away if it does not get what it wants - which looks like most of the benefits of wedlock without any of the obligations. (The Guardian, Britain and EU: the breakdown of a decades-long marriage, March 29, 2017)

d. Elizabeth Corley, vice-chairman of Allianz Global Investors, showed a more realistic view of relationships when she said last week that, were the UK to walk out on the $E U$, it would result in "an annoying divorce" in which the renegotiation of trade deals would take between five and 10 years. (Evening Standard, Patience Wheatcroft: Reform, not divorce, is the best way for Britain in Europe, April 13, 2016)

e. Brexit: An often rocky marriage ends in sudden divorce (CNN, June $25,2016)$ 
f. In the letter, May said the two sides should "engage with one another constructively and respectfully, in a spirit of sincere cooperation." But for all the warmth, the next two years will be a tough test of the notion that divorcees can remain good friends. (The Denver Post, It's not EU, it's me: UK files for EU divorce after 44 years, March 29, 2017)

In the examples in (1), Britain's exit from the EU is conceptualized as a love relationship coming to an end and subsequently ending in divorce. In these examples, despite the hopes that the UK and the EU will stay in a relationship and avoid breakup, their rocky marriage ends up in divorce, after Britain decides to walk out on the EU. The UK hopes to keep the benefits of wedlock without any of the obligations and to remain good friends with its ex. The abovementioned metaphorical linguistic expressions, used in the examples in (1), can be regarded as a conventional way of speaking about political agreements in terms of marriage and their termination in terms of divorce.

However, apart from conventional figurative language used in the debate on Brexit, the popularity of this political issue has also made room for creativity when it comes to the use of figurative language, that is, figurative creativity. Therefore, examples (2), (3) and (4) contain figurative language which is not conventionally used and thus can be regarded as creative figurative language.

(2) The EU institutions, in particular the commission, should take a leading role in the process. To play that part, however, its exclusivist style of leadership must change. The commission must become a force for inclusion, not an agent of the "core". It must reinvent itself as a kind of marriage counsellor to prevent another divorce in the European family. This is what acting "politically" means in the EU context. (Financial Times, EU institutions must share some of the blame for Brexit, June 30, 2016)

(3) So, will it be the bad-tempered breakup, a passionate, crazily romantic bid for independence and the liberty of a single life - followed, in all likelihood, by years of acrimonious wrangling over the furniture?

Or will it be kiss and make-up: a rational decision to remain in what has, in truth, often seemed a rather tedious, restrictive, even loveless marriage of convenience - but one, nonetheless, that has brought both parties many benefits? (The Guardian, Britain and the EU: the story of a very rocky marriage, June 23, 2016)

(4) Then in The Times, David Aaronovitch criticised attempts to do deals with Brussels saying: "It is as if a spouse sues for divorce, demands the house and then suggests popping round every now and then for a quickie." (Daily Express, Stop calling Brexit "a divorce" - we were never married to the idea of the EU, July 30, 2016)

Examples of creative figurative language (2)-(4) can be viewed as conceptual blends, motivated by the MARRIAGE/DIVORCE metaphor. 


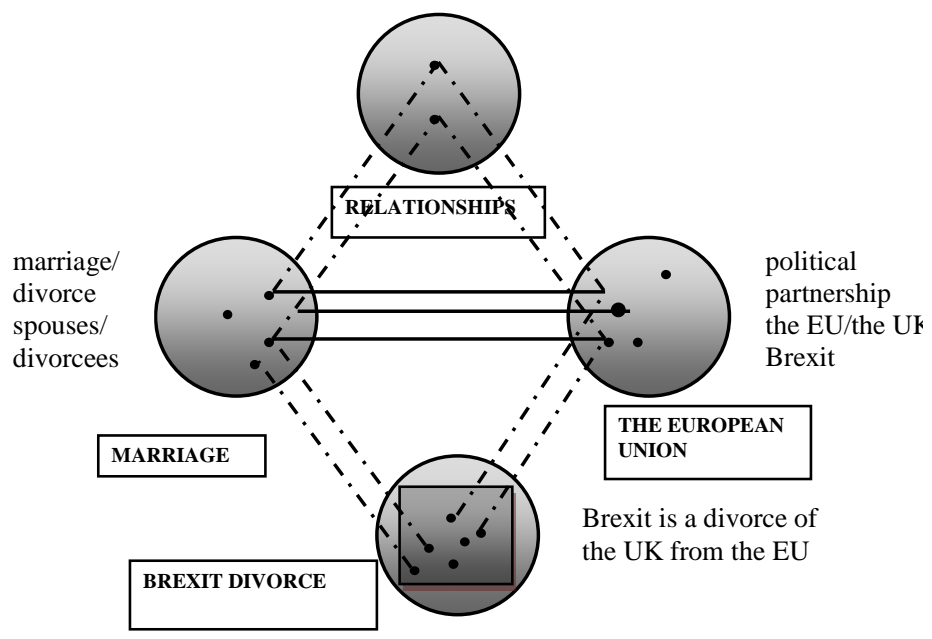

Figure 4. The conceptual integration network for the divorce metaphorical blend.

These conceptual integration networks are composed of two input spaces. The source input space, the divorce input, contains our knowledge about human relationships and concepts of love, family and marriage. The target input space, the EU space, contains the European Union as a political, legal, and economic union of 28 different European countries, with common laws and policies regulating the relationships between the member states.

Cross-space mappings between the source and target input connect the spouses to the EU and the UK, marriage to the political, economic and legal agreements between the EU and the UK, and divorce to Brexit. As all other metaphorical blends, these blends are also asymmetric, inheriting the organizing frame from the source, that is divorce, input. Projected to the blend from the source input are the concepts of a bad marriage ending up in divorce and legal proceedings. From the target input, projected to the blend are the EU and the UK and the UK's decision to leave the EU.

However, apart from these projections, the blends in (2), (3) and (4) receive other various portions of conceptual material, which are activated and projected to the blend. In this way the source concept initiates the construction of a richer image in the blend. Different aspects of marriage and divorce concepts, ranging from marriage counsellor to post-divorce life of divorcees, are projected from the source domain to the blend, producing more creative conceptual blends.

In that sense, the blend in (2) receives additional projections which include marriage counsellor from the source input and the European Commis- 
sion from the target input. In the blend, the EU institutions must act as marriage counsellors to prevent another divorce in the EU family. It should be noted that in the blend the EU, represented by the European Commission, is both a divorcee and a marriage counsellor, and is in a polygamous marriage with each member state, which opposes the logic of the source input. Therefore, the causal structure is projected to the blend from the target input logic in which the European Commission acts as both a mediator between and a marriage partner of member states.

The blend in example (3) receives additional projections from both inputs. From the source input, the blend receives projections which include the consequences of a divorce, the reasons for a divorce, such as a wish of one partner for independence, as well as the possibility of divorce proceedings turning into a long fight over everything, including furniture, and the consequences of staying in a loveless marriage due to convenience. Projected from the target input space is the leave or stay vote in Brexit referendum. In the blend, the referendum decides on the UK's fate, that is, whether it will stay in the loveless marriage or whether it will enjoy freedom and liberty of the single people.

The blend in (4) receives additional projections from the source input, which include the demands of the spouses related to the family assets, and behaviour of ex-spouses who often engage in sexual relations with each other even after divorce. From the target input, projected to the blend are the Brexit negotiations between the UK and Brussels.

The figurative creativity in these examples arises from the source input space of divorce which is very general and contains the complete encyclopaedic knowledge about marriage and divorce concepts. In addition, the existence of the overarching FAMILY metaphor also implies the existence of conceptual associations between family and politics residing in human minds, which feed the conceptual integration processes and contribute to further creative exploitation of the metaphor.

In addition, innovative conceptual blends exploit the rich background knowledge of the source inputs by activating the aspects of the source that are not conventionally used metaphorically, creating novel and even more elaborate blends. It should be noted that the background knowledge about the EU and the relationships between the member states is also of importance. In that sense, in the blend in (2), Brexit is not a simple political divorce, but it includes marriage counsellors. In the blend in (3), Brexit could turn into an endless legal battle over trivial things but it could lead Britain to independence or it could mean staying in a loveless marriage of convenience. In the blend in (4), the UK, having started the divorce proceedings, wants to keep the assets, but at the same time wishes to maintain occasional (sexual) relations with the EU. 
Therefore, these blends exploit rather marginal aspects of the source concept. These aspects do not belong to conventional associations between the domains, which are part of the human conceptual repertoires. Therefore, these blends exploit the aspects of the source concept that are not conventionally used metaphorically, producing more radical examples of figurative creativity. Thus, recruiting marginal aspects of the MARRIAGE/DIVORCE concept, which are not part of conventional associations between the domains, produces more striking examples of figurative creativity, both linguistically and conceptually.

The prominence of the MARRIAGE/DIVORCE metaphor formed a microtradition of discussing Brexit in the British public discourse in terms of a troubled marriage ending in divorce. In addition, by using the metaphorical linguistic expressions of the MARRIAGE/DIVORCE metaphor or using this metaphor as motivation for imaginative conceptual blends, different texts on the same topic, namely Brexit, are intertextually connected, providing discourse coherence. Therefore, the prominence of the MARRIAGE/DIVORCE metaphor among the members of the discourse community, and its further creative exploitation, reinterpretation, and modification in conceptual blends provides discourse coherence at intertextual level.

In addition, apart from simply using the metaphor or metaphorical blends in discourse, members of the discourse community maintain intertextual relations between texts by alluding to or commenting on the statements formulated in figurative language by refuting or supporting a particular statement by using figurative language produced by the same metaphor or blend. Very often, both the statements and the comments are expressed in creative figurative language, produced in a metaphorical blend motivated by the same conceptual metaphor, which is the case in example (5). In this example, both the statement and the comment are expressed in creative figurative language produced by the divorce blend. Therefore, creative figurative language constitutes an important part in keeping virtual conversations ${ }^{8}$ alive within a discourse community.

(5) Just when you were beginning to wonder whether we have done the right thing, along comes Jean-Claude Juncker to remind you exactly why Britain voted for Brexit. It is 'not going to be an amicable divorce', he tells us.

Why can't it be amicable? We've decided that we've grown apart, not run off with the milkman. There's no need to put the car keys down the drain and upload some naked photos onto the web. It isn't so much Ukip who are exploiting the politics of hate; it is Juncker. In his desire for re-

\footnotetext{
${ }^{8}$ Musolff (2004a: 5, passim) uses the term virtual conversations to refer to discussions of a particular issue within a discourse community. Needless to say that metaphors play an important role in virtual conversations on a particular topic. In addition, in virtual conversations, a history of a particular metaphor and its elaboration can be tracked.
} 
venge he is demonstrating the contempt for democracy that has been the bane of European Commission ever since it was founded. (The Spectator, Why can't we have an amicable divorce with the EU?, June 26, 2016)

As in other creative examples discussed, the blend in example (5) is modified by additional projections of marginal conceptual material from the source input including the relationship of the divorcees during the proceedings, the possible reasons for a divorce such as emotional distance between partners or adultery, as well as the behaviour of a partner with hurt feelings because of the divorce. In the blend, the divorce between the EU and the UK, despite the contrary views, should be amicable considering the reasons for the split were not to hurt the EU. Therefore, in the blend in (5), Brexit divorce should be amicable, despite Junker's claims, without the EU retaliating by posting naked photos on the Internet or putting the car keys down the drain.

In addition, a meta-metaphorical comment is used in the following text to warn the reader that Brexit will be discussed in metaphorical terms in the rest of the text, in which the author is trying to explain what the leave vote actually means. In addition to activating the divorce blend, this metametaphorical comment also establishes intertextual links with other texts in the public discourse on this topic.

(6) The frequently used divorce metaphor is helpful here. All we have done is tell the EU we are unhappy and plan to go. Our relationship has not yet reached the point of no return. True, we have thrown the wedding ring at them and said we're off. We have instructed lawyers. We have lodged the petition. But we have not yet annulled the marriage. If the UK changes its mind before the end of the two-year notice period, then, (most lawyers think, not to mention Lord Kerr, who drafted article 50), we can simply say we have changed our minds, and we want to stay. EU law means never having to say you're sorry. (The Guardian, Yes, we've thrown the wedding ring at the EU. But divorce isn't inevitable, October 19, 2017)

The divorce blend receives projections of marginal conceptual material from the source input, creating a richer image in the modified blend. These projections include the behaviour of an unhappy spouse, the concept of a wedding ring, and the stages of divorce proceedings. In the blend, the UK has thrown the wedding ring, started the divorce proceedings, but the marriage is still valid and it can change its mind and stay.

Apart from providing intertextual coherence, figurative creativity can provide coherence within stretches of texts (6) or even whole texts (7) and (8). Therefore, creative and/or conventional figurative language are combined forming different patterns within texts to provide intratextual coherence. 
In the satirical text in (7) commenting on May's speech in which she tried to explain Brexit decision, the author uses creative figurative language, produced in a metaphorical blend motivated by the MARRIAGE/DIVORCE metaphor, to explain the reasons for Brexit.

(7) "It's not you," she said, looking directly at the ambassadors. "It's us". Britain had simply outgrown the EU and no longer wanted to be constrained by sleeping with only 27 partners. Britain wanted to go and shag the rest of the world. We had asked for an open marriage and the EU had said no, so a divorce was inevitable. But no one should panic. Britain wasn't leaving Europe. Much as we'd like to if that was geographically possible.

Understandably, being dumped live on global TV didn't go down terribly well with the visiting ambassadors. There was a lot of head-shaking and whispering. The Maybot tried not to catch their eye and moved on to the part of her speech marked "Global Britain". (The Guardian, It's not EU, it's us: Maybot outlines Brexit divorce plan, January 17, 2017)

This stretch of satirical text is structured by the creative figurative language, produced in the abovementioned blend, which establishes the coherence within this text. The metaphorical blend, motivated by the MARRIAGE/DIVORCE metaphor, is activated by the use of the cliché expression $I t^{\prime} s$ not you, it's us, which is used by a partner to end a relationship by trying to avoid hurting the other partner's feelings. In the next sentence, maintaining the existing projections and cross-space mappings, the blend receives new projections from the source input, which include the concept of an open marriage and the sexual behaviour of spouses in such marriages. The blend receives additional projections from the target input which include a different type of agreement between the EU and the UK. Cross-space mappings connect the concept of an open marriage from the source input to a more relaxed economic and political arrangement between the EU and the UK. These projections further modify and enrich the image created in the blend and produce even more creative figurative language. The author then continues to explain Brexit in literal language. However, the next paragraph opens with the figurative expression being dumped, which again activates the blend and the scenario of ending a relationship established at the beginning of the text. In the blend, feeling constrained, the UK asks for an open marriage so it could establish (sexual) relations with other countries but the EU rejects the proposal and is being dumped by the UK by the worn-out phrase. It should be noted that, as in example (2), in the blend, the UK is in a polygamous marriage with each member state and thus has 27 sexual partners, which opposes the logic of the source input. Therefore, the causal structure is projected to the blend from the target input logic in which the EU is a union of 28 different countries engaged in political, economic, and administrative relationship with each other. Considering the recurrence of the creative 
figurative language produced in the same metaphorical blend throughout this stretch of text, this blend can be characterized as having a text organizing force, contributing to intratextual coherence of this stretch of text.

Furthermore, creative and conventional figurative language can be combined within texts, providing intratextual coherence of the whole text.

(8) The Britons who voted to divorce from the EU confused a boring marriage with a bad one

There are good reasons to leave a marriage-constant conflict, deep differences, a deranged partner. There are also less good onesconversation's a bit dull, the sex isn't great, or you have the same thing for breakfast every morning.

British voters just called it quits on their 43-year-long marriage with the EU. The 52\% who voted "leave" may have believed they did so over deep-seated and long-held grievances with the status quo: They were on average older and poorer (paywall) than the population at large. Yet their poverty was longentrenched, not necessarily connected with growing economic inequality or foreigners taking jobs, and the regions that voted to leave were those that most depend on trade with the EU. Dull, passionless, and repetitive it may have been, but theirs was a boring marriage, not a bad one.

The Brexit campaign made a simple but alluring appeal to them: "Take back control." And it worked. But some Britons are already realizing the grass isn't magically greener. More than 80 pro-Brexit parliamentarians urged pro-EU prime minister David Cameron to stay in his job for stability's sake; he promptly resigned. The "leave" campaign suggested that divorce proceedings with the EU needn't be too hasty, but Brussels isn't in the mood for delays. As the the pound tanks and stocks tremble, it's getting harder for the Brexit camp to maintain the claim that warnings of an economic wipeout were an elaborate EU plot to bully British voters.

Even nationalist leader Nigel Farage admitted one of his side's key campaign pledges - to redirect funds from the EU budget to the national health service-was "a mistake." And though Boris Johnson, the face of the Brexit campaign and now frontrunner for prime minister, rebuked those such as Farage "who play politics with immigration," the "leave" campaign played plenty of that politics itself, and Johnson may find it hard to put that genie back in the bottle.

Divorce can be thrilling, but in the cold light of the morning after, freedom isn't always such fun. When you "take back control," there's nobody left to blame when things go wrong. (Quartz, The Britons who voted to divorce from the EU confused a boring marriage with a bad one, June 25, 2016)

The text opens with a paragraph explaining good and less good reasons for a marriage ending in divorce, expressed in literal language. However, 
this literal language comes from the source domain of divorce. Considering the fact that the title of the text is formulated in figurative language in which Brexit is conceptualized as divorce, and the prominence of the MARRIAGE/DIVORCE metaphor in public discourse forming intertextual links, the use of literal language related to the real-life divorce in the opening paragraph serves to activate the MARRIAGE/DIVORCE metaphor in the minds of the readers. The next paragraph, explaining the outcome of Brexit referendum, starts with a sentence containing the figurative expression their 43-yearlong marriage with the EU. This expression activates the divorce metaphorical blend, which in the final part of the paragraph is enriched by additional projections from the source input concerning the types of relationships the partners may have in dysfunctional marriages and the reasons for divorce mentioned in the first paragraph. The activation of the blend in this paragraph, now taken into consideration together with the title, makes the reader rethink the first paragraph expressed in literal language in figurative terms. In the blend, although dull, passionless, and repetitive, the marriage between the EU and the UK was a boring marriage, not a bad one.

In the next two paragraphs the author explains the aftermath of Brexit in literal language, with the exception of the conventional figurative expression divorce proceedings with the EU. However, this single conventional expression keeps the blend active in the mind of the reader. The text ends in the creative figurative language explaining what happens when a spouse longing for freedom wakes up and finds out that there is no one to blame when things go wrong. The blend is reactivated and it is enriched by additional projections from the source input, including negative feelings a divorcee can experience after the divorce and situations he/she may go through as a single person. In the blend, the divorce between the EU and the UK could be characterized as being done for the wrong reasons.

The author strategically positions creative figurative language in the headline of the text, then it uses it in the first paragraphs and then picks up the same enriched blend in the final paragraph deliberately to reiterate the message. Other parts of the text contain literal language, with occasional conventional figurative language of the MARRIAGE/DIVORCE metaphor, reminding the reader of the scenario created in the blend. The interplay of conventional and creative figurative language contributes to forming tighter intratextual links within this text. In addition, this example shows that projecting marginal portions of conceptual material from the source space to the blend enriches the image in the blend, which can be further developed and enriched throughout a stretch of text, contributing to intratextual coherence.

Furthermore, whole texts can be structured by creative figurative language produced in a metaphorical blend, as in example (9). The text is structured by a blend used by Boris Johnson, one of the strongest proponents of 
the leave campaign, represented by a combination of citations of portions of Johnson's speech and the author's summary of the speech, beginning and ending with comments provided by the author of the text.

(9) Boris Johnson compares Britain's relationship with the EU to an arranged marriage

Are you sitting comfortably? Boris Johnson would like to tell you an allegorical story about a woman called Britannia.

"I want to tell you a story about a beautiful girl called Britannia, who was persuaded many years ago to go into an arranged marriage with a foreign gentleman who didn't speak much English," the former London mayor told an audience in Bristol.

He said for Britannia it was not an "affair of the heart" but a "commercial transaction", but as the years passed her husband became more "domineering", "controlling" and "needy".

Eventually she decided she didn't have to put up with his unnecessary rules and the uncontrolled visitors to their home - but people told her she couldn't survive on her own.

And this, says Mr Johnson, is the stage we have reached with the EU referendum. Tune in on 23 June to find out if Britannia makes the great escape. (The Telegraph, Boris Johnson compares Britain's relationship with the EU to an arranged marriage, May 14, 2016)

The title of the text and the lead warn the reader that he/she is about to read an allegorical story about a woman called Britannia. The author then summarizes Johnson's speech in which he creatively elaborates and reinterprets the divorce blend. The referendum is a chance for Britannia to make a great escape. The divorce blend is modified by additional projections of marginal conceptual material from both inputs. From the source input, projected to the blend are the concept of an arranged marriage, and behaviour of spouses in the marriage. From the target input, projected to the blend are the EU regulations, its immigration policy, as well as Britannia, a wellknown female personification of Britain. In this blend, the girl called Britannia wants to leave the arranged marriage because her husband became more controlling and needy and keeps making up new rules and inviting guests. The day of the referendum is a chance for Britannia to make a great escape from her controlling husband and loveless arranged marriage. This blend gradually develops in different parts of the text. In this process, the blend is gradually enriched by projections of marginal conceptual material from the source input, while the existing projections and cross-space mappings are maintained. In addition, the blend is also enriched by exploiting cultural models. Therefore, the MARRIAGE/DIVORCE metaphor and the divorce metaphorical blend can be modified and reinterpreted through conceptual blending, producing creative figurative language. 


\section{Conclusion}

Applying blending theory, the paper has analysed innovative conceptual blends, motivated by the conventional MARRIAGE/DIVORCE metaphor, used in the British public discourse in relation to Brexit. This paper has shown that conventional MARRIAGE/DIVORCE metaphor can be creatively stretched through conceptual blending, producing instances of creative figurative language which contributes to achieving discourse coherence at intertextual and intratextual level.

The analysis of the examples from the British public discourse discussing Brexit shows that conventional metaphors and their conventional mappings initiate the launch of conceptual blends. The rich encyclopaedic knowledge about the source concept, that is the concept of marriage/divorce, allows speakers to use certain aspects of the source concept that are not conventionally used metaphorically, enriching the image in the blend and producing novel and even more creative blends. Recruiting marginal facets of the source concept produces more striking examples of figurative creativity, both linguistically and conceptually.

Furthermore, highly creative figurative language produced in conceptual blending can intertextually connect political discourse on the same subject. Alluding to the MARRIAGE/DIVORCE metaphor or using this metaphor as motivation for imaginative conceptual blends, different texts on the same topic are intertextually connected. The analysis shows that the prominence of a certain metaphor can form a micro-tradition of discussing particular issues within a discourse community predominantly in figurative terms. In addition, figurative creativity through blending also contributes to achieving coherence within texts, forming different patterns within texts or stretches of texts and thus producing intratextual links and providing intratextual coherence of texts. Therefore, the creative exploitation, reinterpretation, and modification of a prominent metaphor through conceptual blending in dynamic discourse situations contributes to achieving overall conceptual and textual coherence of public discourse on a particular subject.

This case study also reveals important insights into the ways in which conceptual metaphor and conceptual blending interact. Combining these two cognitive linguistic theories paints a fuller picture of the complex cognitive processes involved in producing figurative creativity in discourse, which contributes to intertextual and intratextual coherence of discourse. In addition, this case study shows that CMT and BT are not only compatible, but they can also benefit from each other, uncovering complex creative processes taking place in human minds. 


\section{References}

Brandt, Line, Per Aage Brandt (2005). Making sense of a blend. A cognitive-semiotic approach to metaphor. Annual Review of Cognitive Linguistics 3: 216-249.

Chaban, Natalia, Jessica Bain, Katrina Stats (2007). Under construction: Images of the enlarging EU in the Australasian news media. Critical Approaches to Discourse Analysis across Disciplines 1(2): 79-95.

Coulson, Seana (1996). The Menendez brothers virus: Analogical mapping in blended spaces. Goldberg, Adele, ed. Conceptual Structure, Discourse, and Language. Stanford: CSLI, 67-81.

Coulson, Seana, Todd Oakley (2000). Blending basics. Cognitive Linguistics 11(3-4): 175-196.

Coulson, Seana, Cristobal Pagán Cánovas (2013). Understanding timelines: Conceptual metaphor and conceptual integration. Journal of Cognitive Semiotics 5(1-2): 198-219.

Đurović, Tatjana, Nadežda Silaški (2018). The end of a long and fraught marriage: Metaphorical images structuring the Brexit discourse. Metaphor and the Social World 8(1): 25-39.

Gibbs, Raymond (2000). Making good psychology out of blending theory. Cognitive Linguistics 11(3-4): 347-358.

Grady, Joseph, Todd Oakley, Seana Coulson (1999). Conceptual blending and metaphor. Gibbs, Raymond, Gerard Steen eds. Metaphor in Cognitive Linguistics. Amsterdam - Philadelphia: John Benjamins, 101-124.

Fauconnier, Gilles (1985). Mental Spaces. Cambridge, Massachusetts: The MIT Press.

Fauconnier, Gilles (2009). Generalized integration networks. Evans, Vyvyan, Stéphanie Pourcel, eds. New Directions in Cognitive Linguistics. Amsterdam Philadelphia: John Benjamins, 147-160.

Fauconnier, Gilles, Mark Turner (2000). Compression and global insight. Cognitive Linguistics 11(3-4): 283-304.

Fauconnier, Gilles, Mark Turner (2001). Conceptual integration networks. Extended version of "Conceptual integration networks." 1998. Cognitive Science 22(2): 133-187, available at <www.markturner.org/cin.web/cin.html>

Fauconnier, Gilles, Mark Turner (2002). The Way We Think: Conceptual Blending and the Mind's Hidden Complexities. New York: Basic Books.

Fauconnier, Gilles, Mark Turner (2006). Conceptual integration networks. Geeraerts, Dirk, ed. Cognitive Linguistics: Basic Readings. Berlin: Mouton de Gruyter, 303371. Reprint of "Conceptual integration networks." 1998. Cognitive Science 22(2): 133-187.

Fauconnier, Gilles, Mark Turner (2008). Rethinking metaphor. Gibbs, Raymond, ed. The Cambridge Handbook of Metaphor and Thought. New York: Cambridge University Press, 53-66.

Koller, Veronika (2004a). Metaphor and Gender in Business Media Discourse: A Critical Cognitive Study. Basingstoke - New York: Palgrave.

Koller, Veronika (2004b). Businesswomen and war metaphors: "Possessive, jealous and pugnacious"? Journal of Sociolinguistics 8(1): 3-23.

Kövecses, Zoltán (2002). Metaphor: A Practical Introduction. New York: Oxford University Press. 
Kövecses, Zoltán (2005). Metaphor in Culture. Universality and Variation. New York: Cambridge University Press.

Kövecses, Zoltán (2008). Conceptual metaphor theory. Some criticisms and alternative proposals. Annual Review of Cognitive Linguistics 6: 168-184.

Kövecses, Zoltán (2009a). Metaphor, culture, and discourse: The pressure of coherence. Zinken, Jörg, Andreas Musolff, eds. Metaphor and Discourse. Basingstoke: Palgrave - Macmillan, 11-24.

Kövecses, Zoltán (2009b). The effect of context on the use of metaphor in discourse. Ibérica 17: 11-24.

Kövecses, Zoltán (2009c). Aspects of metaphor in discourse. Belgrade English Language and Literature Studies (Belgrade BELLS) 1: 81-95.

Kövecses, Zoltán (2010a). Metaphor: A Practical Introduction. (2nd ed). New York: Oxford University Press.

Kövecses, Zoltán (2010b). A new look at metaphorical creativity in cognitive linguistics. Cognitive Linguistics 21(4): 663-697.

Kövecses, Zoltán (2011). Recent developments in metaphor theory: Are the new views rival ones? Gonzálvez-García, Francisco, María Sandra Peña Cervel, Lorena Pérez Hernández, eds. Metaphor and metonymy revisited beyond the Contemporary Theory of Metaphor: Recent developments and applications, Special issue of Review of Cognitive Linguistics 9(1): 11-25.

Kövecses, Zoltán (2015). Where Metaphors Come From: Reconsidering Context in Metaphor. New York: Oxford University Press.

Kövecses, Zoltán (2017). Levels of metaphor. Cognitive Linguistics 28(2): 321-347.

Lakoff, George (1987). Women, Fire, and Dangerous Things. What Categories Reveal about the Mind. Chicago - London: University of Chicago Press.

Lakoff, George (1993). The contemporary theory of metaphor. Ortony, Andrew, ed. Metaphor and Thought. Cambridge: Cambridge University Press, 202-251.

Lakoff, George (1996). Moral Politics: How Liberals and Conservatives Think. Chicago: University of Chicago Press.

Lakoff, George (2016). Understanding Trump. Available at: https://georgelakoff. com/2016/07/23/understanding-trump-2/ Retrieved: June 16, 2018

Lakoff, George, Mark Johnson (1980). Metaphors We Live by. Chicago - London: University of Chicago Press.

Lakoff, George, Mark Johnson (1999). Philosophy in the Flesh: The Embodied Mind and its Challenge to Western Thought. New York: Basic Books.

Lakoff, George, Mark Turner (1989). More Than Cool Reason: A Field Guide to Poetic Metaphor. Chicago: University of Chicago Press.

Matovac, Darko, Goran Tanacković Faletar (2009). TCM i CIT - dvije suprotstavljene teorije ili krajnje točke istoga procesa? Jezikoslovlje 10(2): 133-151.

Musolff, Andreas (2000a). Mirror-Images of Europe: The imagery used in the public debate about European Politics in Britain and Germany. München: iudicium.

Musolff, Andreas (2000b). Political imagery of Europe: A house without exit doors? Journal of Multilingual and Multicultural Development 21(3): 216-229.

Musolff, Andreas (2001). Cross-language metaphors: parents and children, love, marriage and divorce in the European family. Cotterill, Janet, Anne Ife, eds. Language across Boundaries. London - New York: Continuum, 119-134.

Musolff, Andreas (2004a). Metaphor and Political Discourse. Analogical Reasoning in Debates about Europe. Basingstoke: Palgrave. 
Musolff, Andreas (2004b). The heart of the European body politic. British and German perspectives on Europe's central organ. Journal of Multilingual $\&$ Multicultural Development 25(5-6): 437-452.

Musolff, Andreas (2006). Metaphor scenarios in public discourse. Metaphor and Symbol 21(1): 23-38.

Musolff, Andreas (2009). Love, parenthood, and gender in the European family: The British perspective. Renger, Almut-Barbara, Roland Alexander IBler, eds. Europa: Stier und Sternenkranz. Von der Union mit Zeus zum Staatenverbund. Gottingen: V\&R unipress - Bonn University Press, 536-548.

Musolff, Andreas (2010). The Eternal outsider? Scenarios of Turkey's ambitions to join the EU in the German press. Šaric, Ljiljana, Andreas Musolff, Stefan Manz, Ingrid Hudabiunigg, eds. Contesting Europe's Eastern Rim: Cultural Identities in Public Discourse. Bristol: Multilingual Matters, 157-171.

Musolff, Andreas (2016). Political Metaphor Analysis: Discourse and Scenarios. LondonOxford - New York: Bloomsbury.

Musolff, Andreas (2017a). Truths, lies and figurative scenarios: Metaphors at the heart of Brexit. Journal of Language and Politics 16(5): 641-657.

Musolff Andreas (2017b). How metaphors can shape political reality. The figurative scenarios at the heart of Brexit. Papers in Language and Communication Studies 1(1): 2-16.

Petrica, Monica (2011). “Overt" vs. "covert" cultural variance in metaphor usage: 'Europe' vs. Malta and the EU-membership debate. Handl, Sandra, Hans-Jörg Schmid, eds. Windows to the Mind: Metaphor, Metonymy and Conceptual Blending. Berlin - New York: Walter de Gruyter, 143-166.

Ruiz de Mendoza Ibáňez, Francisco J. (1998). On the nature of blending as a cognitive phenomenon. Journal of Pragmatics 30(3): 259-274.

Ruiz de Mendoza Ibáňez, Francisco J., Sandra Peña Cervel (2002). Cognitive operations and projection spaces. Jezikoslovlje 3(1-2): 131-158.

Ruiz de Mendoza Ibáňez, Francisco J., Olga I. Díez Velasco (2003). Patterns of conceptual interaction. Dirven, René, Ralf Pörings, eds. Metaphor and Metonymy in Comparison and Contrast. Berlin: Mouton de Gruyter, 489-533.

Semino, Elena (2002). A sturdy baby or a derailing train? Metaphorical representations of the Euro in British and Italian newspapers. Text 22(1): 107-139.

Semino, Elena (2008). Metaphor in Discourse. Cambridge: Cambridge University Press.

Šarić, Ljiljana (2005). Metaphorical models in EU discourse in the Croatian media. Jezikoslovlje 6(2): 145-170.

Turner, Mark (2007). Conceptual integration. Geeraerts, Dirk, Hubert Cuyckens, eds. The Oxford Handbook of Cognitive Linguistics. Oxford: Oxford University Press, 377-393.

Turner, Mark, Gilles Fauconnier (1995). Conceptual integration and formal expression. Metaphor and Symbolic Activity 10(3): 183-204.

Turner, Mark, Gilles Fauconnier (1999). A mechanism of creativity. Poetics Today 20(3): 297-418.

Turner, Mark, Gilles Fauconnier (2003). Metaphor, metonymy, and binding. Dirven, René, Ralf Pörings, eds. Metaphor and Metonymy in Comparison and Contrast. Berlin: Mouton de Gruyter, 469-487. 
Werkmann, Ana, Gabrijela Buljan (2013). Knocking on EU's door: on the changing and conflicting metaphorical images of Croatia in selected EU press. Jezikoslovlje 14(2-3): 337-362.

Authors' addresses:

Sanja Berberović

Faculty of Humanities and Social Sciences

University of Tuzla

Dr. Tihomila Markovića 1

75000 Tuzla

e-mail: sanja.berberovic@untz.ba

Mersina Mujagić

Pedagogical Faculty

University of Bihać

Žegar, Luke Marjanovića bb

77000 Bihać

e-mail: mersina.mujagic@unbi.ba

Received: May 21, 2018

Accepted for publication: June 12, 2018 